\title{
Effect of Diversity in the Board of Directors and Top Management Team on Corporate Social Responsibility
}

\author{
Priscila Prudêncio ${ }^{1}$ \\ priscilaprudencio.ufc@gmail.com | (D) 0000-0003-4219-3544 \\ Hyane Forte ${ }^{1}$ \\ hyane_0104@hotmail.com | (10)0000-0002-9559-5267 \\ Vicente Crisóstomo ${ }^{1}$ \\ vicentelc@gmail.com | (D) 0000-0002-8593-0471 \\ Alessandra Vasconcelos ${ }^{1}$ \\ alevasconcelos.ufc@gmail.com | (D) 0000-0002-6480-5620
}

\begin{abstract}
This study analyzes the effect of corporate governance, with an emphasis on gender and age diversity in the board and Top Management Team, on Corporate Social Responsibility in Brazil. The sample was composed of Brazilian firms with corporate governance published in the CVM reference form, financial information in the Economática ${ }^{\circledR}$ database, and CSR assessed by the CSRHub database, in the 2016-2017 biennium, with a total of 194 firm-year observations. Diversity is measured by the presence of women, age heterogeneity, and average age in the board of directors and top management team. The results indicate that gender diversity in the board of directors and the higher average age of the top management team have a favorable effect on the CSR practices of Brazilian firms. Additionally, it was observed that age heterogeneity among board members has a negative influence on CSR practices. The research contributes to a better understanding of the behavior of more diverse boards of directors and top management teams regarding CSR strategies.
\end{abstract}

\section{KEYWORDS}

Corporate social responsibility, corporate governance, gender diversity, age diversity

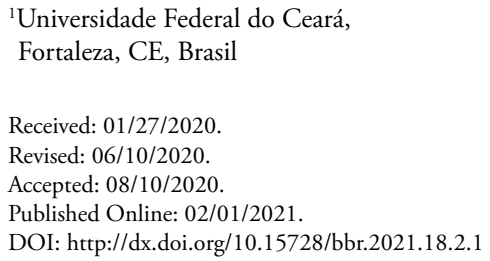




\section{INTRODUCTION}

In the current business context, firms have intensified their search for better corporate governance strategies, since the business environment has become more competitive (Macedo, Oliveira, Nobre, Brito, \& Quandt, 2015; Rocha, Santos, De Luca, \& Vasconcelos, 2014). The adoption of good corporate governance practices is considered capable of strengthening a firm's competitiveness and image, in addition to influencing business performance (F. T. de Almeida, Parente, De Luca, \& Vasconcelos, 2018; Ferrero-Ferrero, Fernández-Izquierdo, \& Muñoz-Torres, 2013; Taghizadeh $\&$ Saremi, 2013). According to the literature, governance discusses the relationship of all the actors in an organization, with the board of directors and executive management as the main agents (Ferrero-Ferrero et al., 2013; Galbreath, 2011; Macedo et al., 2015).

The board of directors has considerable power and responsibilities regarding firm strategies and influence over decision making (Ferrero-Ferrero et al., 2013; Galbreath, 2011). The top management team interacts with the board of directors in order to comply with established strategies. Studies suggest that diversity in the board of directors and top management team, in terms of gender or age, can have an effect on firm's strategic decisions (Bear, Rahman, \& Post, 2010; Jizi, 2017; Post, Rahman, \& Rubow, 2011; Rao \& Tilt, 2016a, 2016b). Nowadays, Corporate Social Responsibility (CSR) has become a business strategy.

CSR can be considered an important management paradigm that decision makers seek as an additional instrument to obtain competitive advantage (Galbreath, 2011; Rao \& Tilt, 2016a). This is due to the fact that CSR basically corresponds to a wider responsibility of the firm to its stakeholders (Rao \& Tilt, 2016a). The literature also suggests that the top management has a relevant role regarding the undertaking of CSR strategies, also moderated by the board of directors (Al-Shaer \& Zaman, 2016; Ferrero-Ferrero et al., 2013; Ibrahim \& Hanefah, 2016; Rao \& Tilt, 2016b, 2016a).

The existence of a diversified top management team, regarding gender and/or age of its members, has helped to expand the debate concerning firms's strategic policies (Ferrero-Ferrero et al., 2013), favoring CSR policies (Silveira \& Donaggio, 2019). The wide debate has introduced the idea that CSR policies can be beneficial to the firm, given that higher commitment to different stakeholders can contribute to improving firm image, as proposed by the Stakeholder approach (Glass, Cook, \& Ingersoll, 2016).

Given the relevance of CSR and the trend towards more gender and age diversity in boards and top management teams, this research aims to analyze the effects of the diversity of the composition of the board of directors and top management teams on the corporate social responsibility policy of Brazilian firms.

The low presence of women on the board of directors of Brazilian firms was the motive behind the creation of Senate Bill No. 112/2010 and Senate Bill No. 398/2016. Senate Bill No. $112 / 2010$ aimed to establish a minimum proportion of women on the board of directors of entities belonging to indirect public administration: state companies and mixed-capital companies. Senate Bill No. 398/2016 proposed a minimum proportion for each gender in board seats of all public companies. Similar affirmative actions on gender diversity in firms' boards and top management teams have been adopted in different countries in Europe (Silva \& Margem, 2015).

The composition of the board of directors has historically been characterized by a huge presence of men with an average age of over 50 years. Sant'anna and Bruzoni Júnior (2019), when analyzing the average age of the board of directors of Brazilian firms from 2010 to 2017, documented an average age of 54 years. The Brazilian Institute of Corporate Governance [IBGC] (2016), when analyzing 2,244 board seats of 339 companies listed on B3 in 2015, found that $70.05 \%$ of the 
directors were between 50 and 70 years old. Thus, given the difficulty in diversifying a firm's board and top management team, this study is justified by the need to gain a better understanding of firm management strategies in CSR actions. Research on the relationship between the diversity of board, top management team, and CSR practices has been considered as relevant and this motivates the development of this work (Ferrero-Ferrero et al., 2013; Post et al., 2011; Silveira \& Donaggio, 2019).

A sample of 194 firm-year observations of publicly traded companies listed on B3 S.A. (Brazil, Bolsa, Balcão), with institutional, governance, and financial information on the CVM reference form and on the Economática ${ }^{\varpi}$ and CSR assessment on the CSRHub database, in the 2016-2017 biennium, was analyzed. The CSRHub database provides information on CSR and its dimensions. The CSRHub system allows users to find and compare firm ratings using a CSR rating methodology that is derived from 556 sources of information, such as Asset4, Bloomberg, the Carbon Disclosure Project, Global Reporting Initiative [GRI], Dow Jones Index and United Nations sustainable performance indicators, providing ratings for more than 18,500 companies in 132 countries.

The results indicate that there is a low presence of women in boards and top management teams in Brazilian firms. Furthermore, the directors and executive officers tend to be older, with a high mean age and low age dispersion. The findings reveal that gender diversity on the board of directors and the older top management team have a positive effect on firm CSR practices. The results also show that age dispersion of board members has a negative influence on firm CSR policy.

This work contributes to studies on corporate governance and CSR in Brazil by advancing research on gender and age diversity of board members and top management teams and their possible effect on a firm's adoption of CSR practices. At present, research on diversity in the Brazilian firm seems to be focused on the effects of diversity on performance. Gender diversity in the board of directors and executive management has been assessed as being capable of influencing the firm's performance in two important papers (Dani, Picolo, \& Klann, 2018; Silva \& Margem, 2015). Other works in Brazil make this assessment only with regard to the board of directors (Almeida, Klotzle, \& Pinto, 2013; Costa, Sampaio, \& Flores, 2019; Silva Júnior \& Martins, 2017). Fraga and Silva (2012) assess the influence of age and gender diversity in the board of directors on the firm's performance. Focusing specifically on the relationship between diversity and the firm's CSR performance, Silveira and Donaggio (2019) review and consolidate the recent literature on empirical research in different countries and indicate that gender diversity in the board has positive impacts from a social and environmental perspective, including higher respect for stakeholders, better accountability, and other CSR initiatives.

This research differs from previous studies in that it addresses the diversity of both gender and age in corporate governance - integrating the board of directors, the top management team, and their connection with CSR performance. This enables a clarification of the effects of the diversity of members of the board and top management team on CSR strategies in the Brazilian institutional environment. The results regarding this interaction may be useful for organizations in planning their governance processes.

By presenting a contribution on the possible effects of age and gender diversity in the board of directors and top management team on CSR policy, this paper fills a research gap in Brazil and adds to the results of previous studies in other markets where the issue is already at a more advanced level. Some of these works indicate positive relationships between the gender diversity of senior management and CSR (Al-Shaer \& Zaman, 2016; Ibrahim \& Hanefah, 2016; Jizi, 
2017; Rao \& Tilt, 2016b), while others do not identify a significant relationship or even detect a negative relationship between the constructs (Galbreath, 2011; Giannarakis, 2014; Glass et al., 2016). In addition, surveys that use the age of directors and officers as a proxy for the assessment of executive diversity are still incipient (Ferrero-Ferrero et al., 2013; Giannarakis, 2014; Post et al., 2011).

\section{LITERATURE REVIEW AND HYPOTHESES}

\subsection{CSR AND DIVERSITY IN THE BOARD AND TOP MANAGEMENT TEAM}

Diversity in the board and top management team is understood as a blended combination of attributes, characteristics and experiences of their members (Ibrahim \& Hanefah, 2016; Walt \& Ingley, 2003). Diversity can be measured using demographic data such as sex, age, ethnicity, nationality, educational background and professional experience (Campbell \& Mínguez-Vera, 2008).

In the Brazilian context, the IBGC code of best corporate governance practices includes measures, such as the diversity of profiles, knowledge, experiences, age, and gender of the board of directors (Fraga \& Silva, 2012; IBGC, 2015), as practices capable of improving the decisionmaking process. In this perspective, the literature has treated diversity in both the board of directors and top management team's composition as relevant to the firm's strategic management process (Al-Shaer \& Zaman, 2016; Assenga, Aly, \& Hussainey, 2018; Fuente, García-Sánchez, $\&$ Lozano, 2017). It is considered that the construction of the beliefs and values of directors and top managers may be related to their experiences and origins, and these can influence how they manage and assess the organization (Bear et al., 2010; Post et al., 2011).

In this respect, Hafsi and Turgut (2013) consider that the existence of diversity, in terms such as gender and age, in the composition of the board and top management team can also be favorable to the undertaking of CSR policies, since more diversity among these members may allow the emergence of a wider range of favorable opinions and more management sensitivity regarding the preferences, aspirations, and concerns of all the firm's stakeholders. Firm management can also be associated with socially responsible philanthropy, relations with employees, intensity of research and development investment, and environmental litigation (Glass et al., 2016; Hafsi \& Turgut, 2013; Ibrahim \& Hanefah, 2016; Kassinis \& Vafeas, 2002; Post et al., 2011). From this perspective, board characteristics may be able to influence decision making on CSR strategies, considering CSR as a factor capable of improving firm performance (Dani et al., 2018).

According to Rao and Tilt (2016a), firm CSR is established as a critical item on the agendas of the board of directors and the top management team, with both of them being responsible for the achievement of socio-environmental actions. Several studies indicate that diversity in the composition of these two bodies can influence firm CSR (Assenga et al., 2018; Bear et al., 2010; Ferrero-Ferrero et al., 2013; Rao \& Tilt, 2016a, 2016b; Walt \& Ingley, 2003).

The demographic diversity of the board of directors and top management team, especially with regard to the gender and age of their members, can play an important role in the definition of CSR strategies (Bear et al., 2010). Some studies also show that the gender diversity of managers, i.e., top management teams with higher numbers of women, can lead to improved communication with society (Bear et al., 2010; Galbreath, 2011). In addition, it is believed that firms with a 
BBR

18

122

higher number of women as managers tend to have a higher level of environmental responsibility (Bear et al., 2010; Ibrahim \& Hanefah, 2016). As for age heterogeneity, it is suggested that a board with a huge age diversity, can take advantage of more distinct information resources, points of view and experience in global markets, and also be more sensitive to stakeholder preferences and influence environmental practices (Ferrero-Ferrero et al., 2013).

Taking stakeholders' needs into account and the important role played by firms concerning social and environmental issues, it is argued that the diversity of top management is a topic that requires more research in order to provide a better understanding of the Corporate Social Responsibility actions.

\section{2. НyPOTHESES}

To Post et al. (2011), a more diverse board of directors and top management team can improve the chances that different knowledge domains, perspectives, values, and ideas will be considered in the decision-making process. In this sense, an analysis of the gender diversity of the board of directors has gained space in issues related to CSR. It has been suggested that female directors have a different set of experiences and skills compared to men that may favor their behavior regarding social and ethical issues (Hafsi \& Turgut, 2013).

Bernardi and Threadgill (2010) found that the presence of women on the top management team increases a firm's socially responsible behavior in three areas: employees, community and charitable contributions. According to the authors, female managers tend to be more open to employees' demands. Moreover, they also tend to be more sympathetic to community and charity issues, being more likely to foster formal employee volunteer programs and combined donation programs (Bernardi \& Threadgill, 2010).

According to Bear et al. (2010), the presence of women on the board of directors can encourage more intense communication between board members and thus lead to the board adopting a more agreeable posture on CSR matters. Furthermore, Fuente et al. (2017) observed that corporate transparency is directly linked to gender diversity in the board, considering that women tend to improve the firm's strategic management by providing a more complete picture of the firm.

Gender diversity in the composition of the top management team can improve the firm's relationship with customers and influence the social dimension of sustainability, considering that customers are relevant stakeholders (Galbreath, 2011). Hafsi and Turgut (2013) found that the presence of women in the top management team results in improved social performance. They attribute this outcome to the fact that women are more sensitive to CSR issues.

In short, under the proposals of the Stakeholder Theory, the literature points out that the presence of women in the composition of the board and top management team tends to contribute to a better relationship between the firm and the community, and to better communication with its stakeholders. This favors the firm's sensitivity to the needs and requirements of stakeholders, and the maintenance of a more favorable position regarding the creation of sustainable value for the organization.

Based on the theoretical arguments and previous empirical findings, it is suggested that the presence of women in the board and top management team favors firm CSR policy, as proposed by the following hypotheses: 
- Hypothesis 1a: The presence of women on the board of directors positively influences the CSR of Brazilian firms.

Hypothesis 1b: The presence of women on the top management team positively influences the CSR of Brazilian firms.

Diversity in the composition of the board of directors and top management team has another important attribute, the age heterogeneity of their members. The age of the members of these bodies reflects the level of general experience that they have, in addition to their maturity in relation to the business. As a matter of principle, younger executives are considered more sensitive to environmental issues, while older executives are sensitive to the well-being of society (Hafsi \& Turgut, 2013; Post et al., 2011). This sensitivity leads to more responsible behavior in relation to social and environmental concerns (Hafsi \& Turgut, 2013).

Ferrero-Ferrero et al. (2013) confirm that the age heterogeneity of board and top management team members provides stronger informative power to firm decision-making, as well as richer experiences in global markets. In addition, their results indicate that age heterogeneity allows a broader approach to financial and extra-financial aspects, encouraging the adoption of sustainable issues.

It is known that the interests of stakeholders are not restricted to financial actions, but involve several environmental, social and governance issues (Ferrero-Ferrero et al., 2013). Greater age heterogeneity of the firm's senior staff members is seen as being capable of improving the firm's sensitivity to stakeholders' demands, leading it to integrate CSR actions into its organizational policies, strengthening its image and reputation. Thus, regarding the age heterogeneity of board and top management team members, the following assumptions can be made:

- Hypothesis 2a: Higher age heterogeneity among board members positively influences the CSR of Brazilian firms.

- Hypothesis 2b: Higher age heterogeneity among the top management team members positively influences the CSR of Brazilian firms.

The moral capacity acquired by the individual throughout his/her life may favor his/her interest in promoting actions that contribute towards the welfare of society. From this perspective, the stronger concern of the board and top management team with stakeholders' needs can make firms adopt a more sustainable approach in strategic planning, favoring the firm's image and reputation. In this context, Post et al. (2011) found that older board members are more likely to endorse CSR strategies. This result supports the proposal that an individual's moral capacity may indeed develop over time, favoring his or her concerns over socio-environmental issues. This argument motivates the proposition of the hypotheses suggesting that older board and top management team members favor firm CSR policy:

- Hypothesis 3a: The higher age group of the board members positively influences the CSR of Brazilian firms.

- Hypothesis 3b: The higher age group of top management team members positively influences the CSR of Brazilian firms. 
Based on the six stated hypotheses, the theoretical model for the study is proposed (Figure 1), which shows the main implications expected to emerge from the relationships between diversity among board and top management team members and CSR.

Hypotheses 1 refers to diversity regarding the presence of women on the board of directors and top management team, while Hypotheses 2 and 3 address age and age group.

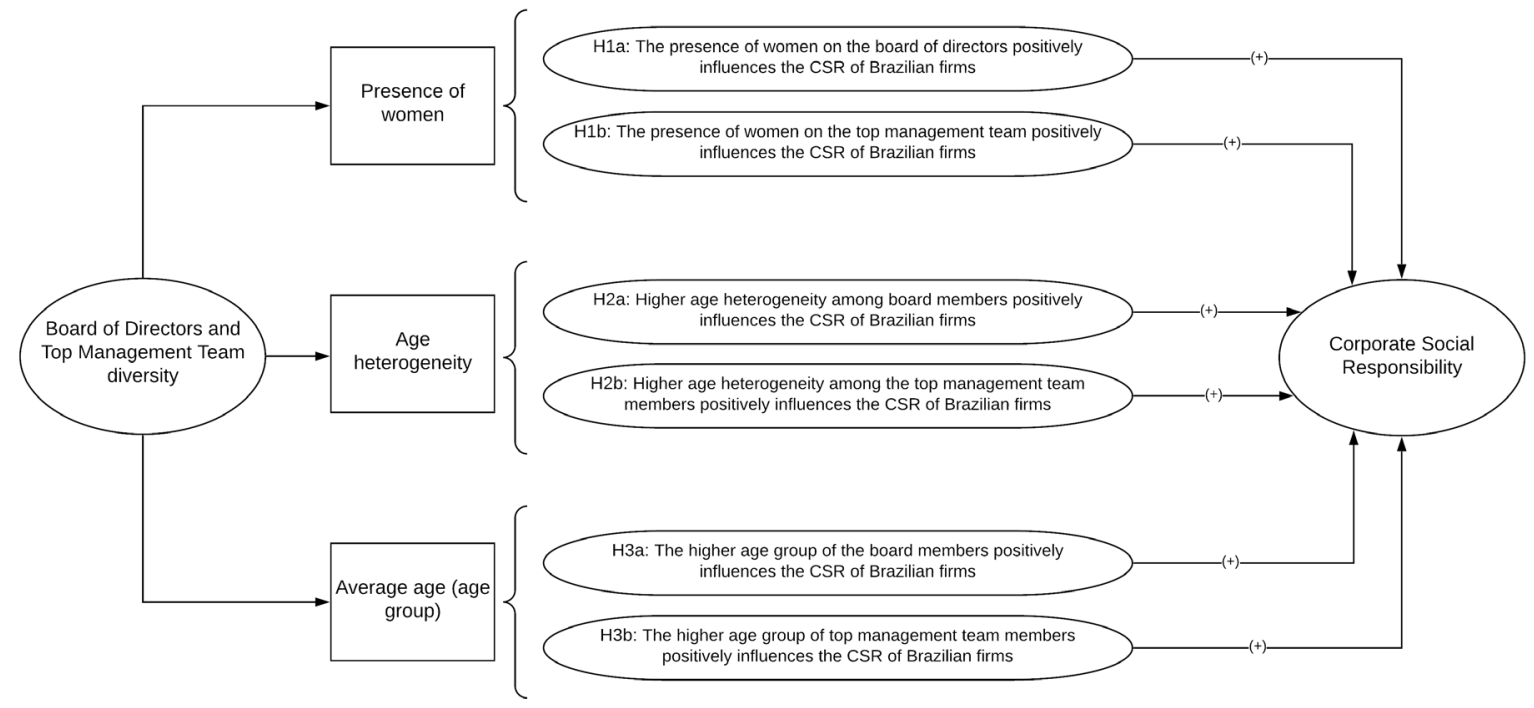

Figure 1. Theoretical research model.

Source: Prepared by the authors.

\section{SAMPLE AND METHODOLOGY}

\subsection{SAMPLE}

The research population consists of all firms listed on B3 S.A., which corresponds to 371 firms. From this population, the firms in the sample are the ones that provided information in the reference form, in the Economatica ${ }^{\circledR}$ database and that were evaluated by CSRHub from 2016 to 2017 . With the intention of sampling more relevant firms with more visibility, data were collected from the firms most active in the Brazilian stock market, considering those whose shares had a liquidity index of at least 0.1 in the years in question. The sample consists of 194 firm-year observations. The sample relevance is confirmed by its market share and also by its high market capitalization. The market value of sample firms corresponds to approximately $82 \%$ of all firms' market value traded on B3 S.A. at the end of December in the years surveyed, according to data provided by Economatica ${ }^{\oplus}$. Furthermore, the sample firms are distributed over an ample set of economic activity sectors, which is important in works of this nature, in order to avoid industry bias (Table 1 ). 
Table 1

Distribution of sample firms by industry

\begin{tabular}{lcc}
\hline Sector & $\mathrm{N}$ & $\%$ \\
\hline Food and drinks & 14 & 7.22 \\
Trade & 14 & 7.22 \\
Construction & 11 & 5.67 \\
Electricity & 30 & 15.46 \\
Finance and Insurance & 22 & 11.34 \\
Mining, Steel and Metallurgy & 11 & 5.67 \\
Industrial Machinery, Vehicles and Parts & 6 & 3.09 \\
Chemistry, Cellulose, Oil & 18 & 9.28 \\
Telecommunications, Software and Data & 10 & 5.15 \\
Textiles & 6 & 3.09 \\
Transport & 10 & 5.15 \\
Others & 42 & 21.65 \\
\hline Total & 194 & 100 \\
\hline
\end{tabular}

\subsection{Models ANd VARIABLes}

The CSRHub was launched in 2008 with the aim of encouraging transparency and the dissemination of consistent and reasonable information from different types of firms. The CSRHub agency is ranked among the top five sustainability ratings in the world. Currently, the CSRHub presents information on the social responsibility and corporate sustainability of 18,554 companies in 132 countries (CSRHub, 2019).

The CSRHub database integrates different data sources related to environmental, sustainability, and governance indicators, being considered one of the most comprehensive CSR assessment databases in the world. It is noteworthy that CSRHub adheres to the guidelines of the Global Reporting Initiative (GRI) (Aggarwal, 2013; Mohamed \& Salah, 2016) which is presently the most widespread non-financial reporting tool worldwide (Mohamed \& Salah, 2016; Skouloudis, Evangelinos, \& Kourmousis, 2009).

The CSRHub defines rules related to CSR performance assessment and disclosure of CSR actions as a whole and by CSR dimension. The CSRHub's assessment of firm CSR data takes into account 4 main dimensions: community, employees, environment, and governance. Each dimension comprises 3 subdimensions (Chart 1).

Chart 1

CSRHub dimensions and subdimensions

\begin{tabular}{|c|c|c|c|}
\hline Community & Employees & Environment & Governance \\
\hline $\begin{array}{c}\text { Community development } \\
\text { \& Philanthropy }\end{array}$ & $\begin{array}{c}\text { Compensation and } \\
\text { benefits }\end{array}$ & $\begin{array}{c}\text { Energy and climate } \\
\text { change }\end{array}$ & Board \\
\hline Product & Diversity and labor rights & $\begin{array}{c}\text { Environment policy and } \\
\text { reporting }\end{array}$ & Leadership ethics \\
\hline $\begin{array}{c}\text { Human rights \& Supply } \\
\text { chain }\end{array}$ & $\begin{array}{c}\text { Training, safety and } \\
\text { health }\end{array}$ & Resource management & $\begin{array}{c}\text { Transparency and } \\
\text { reporting }\end{array}$ \\
\hline
\end{tabular}

Source: Adapted from CSRHub (2019). 
BBR

18

126

Each dimension assessment has a score on the scale from 0 to 100. Thus, in this work, the dependent variable (CSR) will be operationalized through the general CSRHub evaluation metric. The general evaluation metric is computed as the arithmetic mean of the four categories' scores, thus varying between 0 and 100. It is noteworthy that the use of the CSRHub to assess firm CSR performance is increasing in the international literature (Arminen, Puumalainen, Pätäri, \& Fellnhofer, 2018; Bouvain, Baumann, \& Lundmark, 2013; Hughey \& Sulkowski, 2012; Kang \& Fornes, 2017; Mohamed \& Salah, 2016, Vaia, Bisogno, \& Tommasetti, 2017; Westermann, Niblock, \& Kortt, 2019).

An additional metric was prepared, taking into account only three dimensions of the CSRHub - community, employees, environment - which are the three most traditionally CSR dimensions associated with CSR (CSR_EEC). This particular CSR construct, with only these three dimensions, allows for a more accurate assessment, given that the factors hypothesized as capable of influencing CSR are components of the corporate governance structure.

For the analysis, a descriptive study of CSR and diversity data was conducted, and econometric models were defined in order to assess the explanatory capacity of diversity over CSR. Diversity on the board (DIVER_BOARD) and top management team (DIVER_EXECUTIVE) are obtained by means of three variables: presence of women on the board of directors and/or top management team; age heterogeneity on the board of directors and/or top management team members; and age group (average) of the board of directors and/or top management team members. In addition, relevant control variables are inserted in the models: board size (SIZE_ BOARD), board independence (IND_BOARD), number of members on top management team (SIZE_EXECUTIVE), firm profitability (ROA) and firm size (SIZE). Thus, the following econometric models are proposed:

$$
\begin{aligned}
& \text { CSR }=\beta_{0}+\beta_{1} \text { DIVER_BOARD } D_{\text {it }}+\beta_{2} \text { SIZE_BOARD }_{\text {it }}+\beta_{3} \text { IND_BOARD }_{\text {it }}+\beta_{4} \text { ROA }_{\text {it }}+\beta_{5} \text { SIZE }_{i t}+\varepsilon \\
& \operatorname{CSR}=\beta_{0}+\beta_{1} \text { DIVER_EXECUTIVE }_{i t}+\beta_{2} \text { SIZE_EXECUTIVE }_{\mathrm{it}}+\beta_{3} \text { ROA }_{\mathrm{it}}+\beta_{4} \operatorname{SIZE}_{\mathrm{it}}+\varepsilon \\
& \mathrm{CSR}=\beta_{0}+\beta_{1} \text { DIVER_BOARD }_{\text {it }}+\beta_{2} \text { DIVER_EXECUTIVE }_{\mathrm{it}}+\beta_{3} \text { SIZE_BOARD }_{\mathrm{it}}+\beta_{4} \text { IND_BOARD }_{\text {it }} \\
& +\beta_{5} \text { SIZE_EXECUTIVE }_{\mathrm{it}}+\beta_{6} \mathrm{ROA}_{\mathrm{it}}+\beta_{7} \mathrm{SIZE}_{\mathrm{it}}+\varepsilon
\end{aligned}
$$

Chart 2 summarizes the models' variables, presenting the variable (construct) name, its calculation, source of collection, theoretical basis and expected effect on CSR.

The age of each top management team officer or director was calculated from the date of birth available on the CVM reference form (item 12.5/6) until the date of information disclosure. The age heterogeneity was then calculated, approximated by the age variation coefficient of top management team members or of the board of directors. Gender diversity, in turn, was obtained by consulting the name of each member. If the name did not allow immediate gender identification, the firm page was consulted and, in some cases, even social networks were tracked.

The models were estimated by Ordinary Least Squares (OLS) robust to heteroscedasticity. Tests for multicollinearity were performed by means of the variance inflation factors (VIF) for the independent variables of each model. With VIF values between 1 and 10, there is no multicollinearity problem (Bejar, Mukherjee, \& Moore, 2011; Deshmukh, Goel, \& Howe, 2013). 
Chart 2

Description of model variables

\begin{tabular}{|c|c|c|c|c|c|}
\hline Construct & $\begin{array}{l}\text { Dependent } \\
\text { variables }\end{array}$ & Calculation & Source & \multicolumn{2}{|c|}{ Theoretical basis } \\
\hline \multirow[t]{2}{*}{$\begin{array}{l}\text { Corporate } \\
\text { social } \\
\text { responsibility } \\
\text { (CSR) }\end{array}$} & CSR & $\begin{array}{l}\text { General CSRHub } \\
\text { metric: community, } \\
\text { employees, } \\
\text { environment and } \\
\text { governance }\end{array}$ & $\begin{array}{l}\text { CSRHub } \\
\text { database }\end{array}$ & \multicolumn{2}{|c|}{$\begin{array}{c}\text { Arminen et al. (2018); } \\
\text { Bouvain, Baumann \& } \\
\text { Lundmark (2013); Hughey } \\
\text { e Sulkowski (2012); Kang \& } \\
\text { Fornes (2017); Mohamed \& } \\
\text { Salah (2016); Vaia, Bisogno } \\
\text { \& Tommasetti (2017); } \\
\text { Westermann, Niblock \& Kortt } \\
\text { (2019) }\end{array}$} \\
\hline & CSR_EEC & $\begin{array}{l}\text { Average of variables: } \\
\text { community, } \\
\text { employees and } \\
\text { environment }\end{array}$ & $\begin{array}{l}\text { CSRHub } \\
\text { database }\end{array}$ & \multicolumn{2}{|c|}{$\begin{array}{c}\text { Bouvain, Baumann } \\
\text { \& Lundmark (2013); } \\
\text { Thanetsunthorn \& } \\
\text { Wuthisatian (2016) }\end{array}$} \\
\hline Construct & $\begin{array}{l}\text { Independent } \\
\text { variables }\end{array}$ & Calculation & Source & Theoretical basis & $\begin{array}{c}\text { Expected } \\
\text { signal }\end{array}$ \\
\hline \multirow{3}{*}{$\begin{array}{l}\text { Diversity of } \\
\text { the board } \\
\text { of directors } \\
\text { (DIVER_- } \\
\text { BOARD) }\end{array}$} & $\begin{array}{l}\text { Women on the } \\
\text { board of directors } \\
\text { (PW_BOARD) }\end{array}$ & $\begin{array}{c}\text { Proportion of women } \\
\text { on the board of } \\
\text { directors }\end{array}$ & Reference form & $\begin{array}{l}\text { Bernardi \& } \\
\text { Threadgill (2010); } \\
\text { Glass et al. (2016) }\end{array}$ & + \\
\hline & $\begin{array}{l}\text { Age heterogeneity } \\
\text { of the board of } \\
\text { directors (AGE_- } \\
\text { CV_BOARD) }\end{array}$ & $\begin{array}{c}\text { Coefficient of } \\
\text { variation in the age } \\
\text { of board of director } \\
\text { members }\end{array}$ & Reference form & $\begin{array}{l}\text { Ferrero-Ferrero et } \\
\quad \text { al. }(2013)\end{array}$ & + \\
\hline & $\begin{array}{l}\text { Age group of the } \\
\text { board of directors } \\
\text { (AGE_AVE_- } \\
\text { BOARD) }\end{array}$ & $\begin{array}{l}\text { Average age of the } \\
\text { board of director } \\
\text { members }\end{array}$ & Reference form & $\begin{array}{c}\text { Giannarakis } \\
\text { (2014); Post et al. } \\
\text { (2011) }\end{array}$ & + \\
\hline \multirow{3}{*}{$\begin{array}{l}\text { Diversity of } \\
\text { the Executive } \\
\text { Management } \\
\text { (DIVER_- } \\
\text { EXECUTIVE) }\end{array}$} & $\begin{array}{l}\text { Women on the } \\
\text { top management } \\
\text { team (PW_ } \\
\text { EXECUTIVE) }\end{array}$ & $\begin{array}{l}\text { Proportion of } \\
\text { women on the top } \\
\text { management team }\end{array}$ & Reference form & $\begin{array}{l}\text { Bernardi \& } \\
\text { Threadgill (2010); } \\
\text { Glass et al. (2016) }\end{array}$ & + \\
\hline & $\begin{array}{l}\text { Age heterogeneity } \\
\text { of the top } \\
\text { management } \\
\text { team (AGE_CV_- } \\
\text { EXECUTIVE) }\end{array}$ & $\begin{array}{l}\text { Coefficient of } \\
\text { variation in the age } \\
\text { of top management } \\
\text { team members }\end{array}$ & Reference form & $\begin{array}{l}\text { Ferrero-Ferrero et } \\
\quad \text { al. }(2013)\end{array}$ & + \\
\hline & $\begin{array}{l}\text { Age group of the } \\
\text { top management } \\
\text { team (AGE_AVE_ } \\
\text { EXECUTIVE) }\end{array}$ & $\begin{array}{l}\text { Average age of the } \\
\text { top management } \\
\text { team members }\end{array}$ & Reference form & $\begin{array}{c}\text { Giannarakis } \\
\text { (2014); Post et al. } \\
\text { (2011) }\end{array}$ & + \\
\hline
\end{tabular}




\begin{tabular}{|c|c|c|c|c|c|}
\hline Construct & $\begin{array}{l}\text { Independent } \\
\text { variables }\end{array}$ & Calculation & Source & Theoretical basis & $\begin{array}{c}\text { Expected } \\
\text { signal }\end{array}$ \\
\hline \multirow{5}{*}{$\begin{array}{l}\text { Control } \\
\text { variables } \\
(\mathrm{CONT})\end{array}$} & $\begin{array}{l}\text { Board of director } \\
\text { size (SIZE_- } \\
\text { BOARD) }\end{array}$ & $\begin{array}{l}\text { Number of members } \\
\text { on the board of } \\
\text { directors }\end{array}$ & Reference form & $\begin{array}{c}\text { Bernardi \& } \\
\text { Threadgill (2010); } \\
\text { Hafsi \& Turgut } \\
\text { (2013) }\end{array}$ & + \\
\hline & $\begin{array}{l}\text { Independence } \\
\text { of the board of } \\
\text { directors (IND_- } \\
\text { BOARD) }\end{array}$ & $\begin{array}{l}\text { Board of directors' } \\
\text { independence } \\
\text { dummy (value } 0 \\
\text { when there are no } \\
\text { effective independent } \\
\text { directors declared; } \\
\text { value } 1 \text { when } \\
\text { there are effective } \\
\text { independent directors } \\
\text { declared) }\end{array}$ & Reference form & $\begin{array}{l}\text { Hussain, Rigoni } \\
\text { \& Orij (2018); } \\
\text { Ibrahim \& } \\
\text { Hanefah (2016) }\end{array}$ & + \\
\hline & $\begin{array}{l}\text { Number of top } \\
\text { management team } \\
\text { members (SIZE_- } \\
\text { EXECUTIVE) }\end{array}$ & $\begin{array}{l}\text { Number of top } \\
\text { management team } \\
\text { members }\end{array}$ & Reference form & $\begin{array}{l}\text { Hafsi \& Turgut } \\
\quad(2013)\end{array}$ & + \\
\hline & $\begin{array}{l}\text { Firm Return on } \\
\text { assets (ROA) }\end{array}$ & $\begin{array}{l}\text { Net profit / total } \\
\text { assets }\end{array}$ & Economatica $^{\oplus}$ & $\begin{array}{l}\text { Al-Shaer \& } \\
\text { Zaman (2016); } \\
\text { Fuente et al. } \\
(2017)\end{array}$ & + \\
\hline & Firm Size (SIZE) & $\begin{array}{l}\text { Natural logarithm of } \\
\text { total assets }\end{array}$ & Economatica $^{\oplus}$ & $\begin{array}{l}\text { Ricardo, Barcellos } \\
\text { \& Bortolon } \\
\text { (2017); Santana et } \\
\text { al. (2015) }\end{array}$ & + \\
\hline
\end{tabular}

Source: Prepared by the authors.

\section{ANALYSIS OF RESULTS}

Table 2 presents the descriptive analysis of firm CSR and profiles of the board of directors and top management team. It should be observed that there is a certain homogeneity in the level of CSR concerns among the group of firms, as can be seen by the low values of the coefficient of variation of both indicators (CSR and CSR_EEC). It should also be observed that the indicator that does not incorporate the corporate governance dimension (CSR_EEC) presents a slightly higher average, as well as greater dispersion, signaling that this dimension seems to be contributing negatively to the firms' degree of CSR.

The average number of members of the board of directors (SIZE_BOARD) is 10.25, which is within the range of 5 to 11 members recommended by the Brazilian Institute of Corporate Governance (IBGC, 2015), and this number of members is not very dispersed as shown by the coefficient of variation (0.49). Noteworthy is the low female presence on the board of directors (NW_BOARD), since women do not have a seat on the board in $43.3 \%$ of the companies. The average female participation is indeed low (1.02) when compared with the average of 10.25 members on the boards. This low representativeness is most strongly demonstrated by observing the low proportion of women on the board (10\%) (PW_BOARD). These results are similar to those of Post et al. (2011) who found an average female participation of 1.2 counselors in the North American market. 
Table 2

Descriptive analysis of corporate social responsibility, board and top management team

\begin{tabular}{|c|c|c|c|c|c|c|c|}
\hline Variable & & Mean & Median & $\begin{array}{l}\text { Standard } \\
\text { Deviation }\end{array}$ & $\begin{array}{l}\text { Coefficient } \\
\text { of variation }\end{array}$ & Minimum & Maximum \\
\hline \multirow{2}{*}{ CSR } & CSR & 55.00 & 56.00 & 6.28 & 0.11 & 36.00 & 69.00 \\
\hline & CSR_EEC & 58.00 & 58.00 & 7.18 & 0.12 & 35.00 & 74.00 \\
\hline \multirow{7}{*}{$\begin{array}{l}\text { Board of } \\
\text { directors }\end{array}$} & SIZE_BOARD & 10.25 & 9.00 & 5.02 & 0.49 & 3.00 & 29.00 \\
\hline & NW_BOARD & 1.02 & 1.00 & 1.29 & 1.26 & 0.00 & 6.00 \\
\hline & PW_BOARD & 0.10 & 0.08 & 0.11 & 1.15 & 0.00 & 0.42 \\
\hline & AGE_CV_BOARD & 0.18 & 0.18 & 0.05 & 0.28 & 0.06 & 0.37 \\
\hline & AGE_AVE_BOARD & 58.46 & 58.00 & 5.22 & 0.09 & 46.00 & 72.00 \\
\hline & NMIND_BOARD & 3.28 & 3.00 & 2.29 & 0.69 & 0.00 & 11.00 \\
\hline & IND_BOARD & 0.88 & 1.00 & 0.32 & 0.36 & 0.00 & 1.00 \\
\hline \multirow{5}{*}{$\begin{array}{l}\text { Top } \\
\text { management } \\
\text { team }\end{array}$} & SIZE_EXECUTIVE & 7.57 & 6.00 & 10.33 & 1.37 & 1.00 & 93.00 \\
\hline & NW_EXECUTIVE & 0.64 & 0.00 & 0.94 & 1.47 & 0.00 & 5.00 \\
\hline & PW_EXECUTIVE & 0.10 & 0.00 & 0.16 & 1.63 & 0.00 & 1.00 \\
\hline & $\begin{array}{l}\text { AGE_CV } \\
\text { EXECUTIVE }\end{array}$ & 0.13 & 0.12 & 0.06 & 0.47 & 0.01 & 0.31 \\
\hline & $\begin{array}{l}\text { AGE_AVE_- } \\
\text { EXECUTIVE }\end{array}$ & 51.38 & 51.5 & 5.99 & 0.12 & 37.00 & 71.00 \\
\hline
\end{tabular}

Notes. CSR = average of the dimensions of community, employees, environment and governance. CSR_EEC = average of the employees, environment and community dimensions. SIZE_BOARD = number of members on the board of directors. NW_BOARD = number of women on the board of directors. PW_BOARD = proportion of women on the board of directors. AGE_CV_BOARD = age heterogeneity of the members of the board of directors. AGE_AVE_BOARD = average age of the members of the board of directors. NMIND_BOARD = number of independent members of the board of directors. IND_BOARD = dummy of presence of independent directors on the board of directors. SIZE_EXECUTIVE = number of members on the top management team. NW_EXECUTIVE = number of women in the top management team. PW_EXECUTIVE = proportion of women on the top management team. AGE_CV_EXECUTIVE = age heterogeneity of the members of the top management team. AGE_AVE_EXECUTIVE = average age of members of the top management team.

Source: Research data.

As expected, there is a relatively high average age of directors (AGE_AVE_BOARD) (58.46) and with little dispersion (variation coefficient of 0.09 ). This value is also similar to that of the North American market (Post et al., 2011). In turn, the age dispersion is low (average of 0.18). Regarding the independent members (NMIND_BOARD), there is an average of 3 independent members on the board of directors, with cases in which there is no independent director (minimum of 0 ), reaching a maximum of 11 independent members. In addition, $88 \%$ of the boards of directors have at least 1 independent director (IND_BOARD), indicating that there is still a proportion of $12 \%$ of firms that do not comply with this recommendation.

The number of top management team members (SIZE_EXECUTIVE) is highly dispersed, which is indicated by the high coefficient of variation (10.33) and the high discrepancy between the minimum (1 member) and the maximum (93 members). The average number of female executives (NW_EXECUTIVE) is low (0.64), considering that the average number of executives is 7.57. Furthermore, it was found that the average proportion of female executives (PW_EXECUTIVE) is only $10 \%$, with the maximum number of women as executive being 5 , and $50 \%$ of firms have no women in executive positions (median $=0)$. 
Firms have executives with an average age (AGE_AVE_EXECUTIVE) of approximately 51 years, with low variability (coefficient of variation $=0.12$ ), indicating the presence of experienced executives. This age variability is confirmed by the low age heterogeneity in the top management team (AGE_CV_EXECUTIVE) (variation coefficient $=0.06$ ).

Tables 3 and 4 present model estimates that analyze the effect of diversity in the board of directors and top management team on CSR. Table 3 shows the estimation of six models that analyze the effect of diversity on CSR, considering the effect of age heterogeneity. The results indicate that a female presence on the board of directors (PW_BOARD) has a positive effect on CSR (Table 3, models ii, iii, v and vi), as suggested by Hypothesis 1a. Indeed, the presence of women on the board seems to add to the quality of discussions and the establishment of firm CSR. A board of directors with stronger female participation appears to strengthen the firm's relationship with its stakeholders, the argument being that women feel more responsible for the well-being of stakeholders (Byron \& Post, 2016). Furthermore, women make the board more likely to create sustainable value for the firm. The findings are consistent with the studies of Bear et al. (2010) and Galbreath (2011).

Contrary to expectations, the age heterogeneity of the board of directors members (AGE_ CV_BOARD) has a negative effect on CSR (Table 3, models ii and iii). This suggests that the greater the age heterogeneity of board members, the lower the firm's CSR concerns, contrary to the expected positive effect of higher age heterogeneity of board members on the CSR of Brazilian firms (Hypothesis 2a). Hafsi and Turgut (2013) suggest that age diversity might lead to polarization, that is, a kind of generation gap that can lead to an adverse effect on controversial issues which tend to be conducted in a more conservative way. This result is similar to the findings of Hafsi and Turgut (2013).

Contrary to the result of the board of directors, female presence in the top management team (PW_EXECUTIVE) and the age heterogeneity of the top management team members (AGE_CV_EXECUTIVE) have no effect on the CSR of Brazilian firms as expected (Hypothesis $1 \mathrm{~b}$ and $2 \mathrm{~b}$, respectively). This may be due to the fact that a firm's top management team has performance-related obligations that are likely to be prioritized, making actions that are less relevant from a financial performance standpoint less important. In developing markets, this reality is even more striking (Crisóstomo, Freire, \& Vasconcellos, 2011). In such scenarios, including Brazil, female presence in firm direction does not seem capable of imposing a more intense CSR policy. It should also be noted that this presence remains low, as 50\% of the firms were found to have no women on their top management teams (median $=0.00$ ), which can also contribute to the reduced power of female groups when it comes to establishing a more audacious CSR policy.

It was observed that the size of the board of directors (SIZE_BOARD) has a favorable effect on the CSR of the Brazilian firm. More board members can bring more experience and knowledge to the firm, as well as more innovative decisions that can favor CSR actions. This result is in keeping with those of previous studies in different markets (Arena, Bozzolan, \& Michelon, 2015; Rao \& Tilt, 2016b; Said, Zainuddin, \& Haron, 2009).

As expected, larger firms tend to have more intense CSR policies, as shown by the positive effect of firm size (SIZE). According to the literature, larger firms are more visible and society demands more of them, and this status can lead them to be more concerned with socio-environmental and governance issues (Ricardo, Barcellos, \& Bortolon, 2017; Santana, Góis, De Luca, \& Vasconcelos, 2015). Contrary to what was expected, profitability has an adverse effect on CSR in Brazil. This finding is contrary to the proposals of the Slack Resources Theory, which suggests that more profitability can generate financial slack that may favor CSR actions. 
Table 3

Diversity, considering female participation, age heterogeneity and CSR

\begin{tabular}{|c|c|c|c|c|c|c|c|}
\hline \multirow{2}{*}{$\begin{array}{l}\text { Variables } \\
\text { Explanatory }\end{array}$} & \multicolumn{3}{|c|}{$\begin{array}{c}\text { Dependent: CSR (Community, } \\
\text { Employees, Environment and } \\
\text { Governance) }\end{array}$} & \multicolumn{4}{|c|}{$\begin{array}{l}\text { Dependent: CSR_EEC (Employees, } \\
\text { Environment and Community) }\end{array}$} \\
\hline & (i) & (ii) & (iii) & (iv) & & (v) & (vi) \\
\hline \multirow[t]{2}{*}{ PW_BOARD } & & 9.790 ** & $10.352 * *$ & & & $10.197^{* *}$ & $11.434^{*}$ \\
\hline & & $(3.926)$ & $(4.215)$ & & & $(4.435)$ & $(4.658)$ \\
\hline \multirow[t]{2}{*}{ AGE_CV_BOARD } & & $-16.823 *$ & $-17.181 *$ & & & -16.149 & -17.336 \\
\hline & & $(9.156)$ & $(10.143)$ & & & $(10.776)$ & (11.711) \\
\hline \multirow[t]{2}{*}{ PW_EXECUTIVE } & -1.925 & & -1.644 & -3.874 & & & -3.474 \\
\hline & $(2.924)$ & & $(3.027)$ & $(3.273)$ & & & $(3.368)$ \\
\hline \multirow[t]{2}{*}{ AGE_CV_EXECUTIVE } & -4.546 & & 0.580 & -5.565 & & & -0.191 \\
\hline & $(8.027)$ & & $(7.667)$ & $(8.787)$ & & & $(8.288)$ \\
\hline \multirow[t]{2}{*}{ SIZE_BOARD } & & $0.189^{*}$ & $0.225^{* *}$ & & & $0.243^{* *}$ & $0.275^{*}$ \\
\hline & & $(0.108)$ & $(0.110)$ & & & $(0.121)$ & $(0.121)$ \\
\hline \multirow[t]{2}{*}{ IND_BOARD } & & -0.250 & -0.487 & & & -1.588 & -2.048 \\
\hline & & $(1.239)$ & $(1.235)$ & & & $(1.529)$ & $(1.483)$ \\
\hline \multirow[t]{2}{*}{ SIZE_EXECUTIVE } & -0.004 & & -0.025 & -0.036 & & & -0.063 \\
\hline & $(0.028)$ & & $(0.033)$ & $(0.036)$ & & & $(0.041)$ \\
\hline \multirow[t]{2}{*}{ ROA } & -9.040 & $-11.185^{*}$ & $-12.033^{*}$ & -7.780 & & -9.977 & -10.993 \\
\hline & $(6.454)$ & $(6.132)$ & $(6.506)$ & $(6.947)$ & & $(6.629)$ & $(6.948)$ \\
\hline \multirow[t]{2}{*}{ SIZE } & $1.490^{* * *}$ & $1.407^{* * *}$ & $1.436^{* * *}$ & 1.986 & $* * *$ & $1.726^{* * *}$ & 1.862 ** \\
\hline & $(0.377)$ & $(0.292)$ & $(0.374)$ & $(0.437)$ & & $(0.350)$ & $(0.430)$ \\
\hline \multirow[t]{2}{*}{ Constant } & $31.799^{* * *}$ & $32.999^{* * *}$ & $32.641^{* * *}$ & 26.588 & $* * *$ & $30.648^{* * *}$ & $29.418^{* *}$ \\
\hline & $(6.714)$ & $(5.727)$ & $(6.658)$ & $(7.752)$ & & $(6.824)$ & $(7.682)$ \\
\hline $\mathrm{N}$ & 150 & 155 & 149 & 150 & & 155 & 149 \\
\hline $\mathrm{F}$ & 10.90 & 7.18 & 6.00 & 9.84 & & 8.13 & 6.42 \\
\hline $\mathrm{p}$-value & 0.000 & 0.000 & 0.000 & 0.000 & & 0.000 & 0.000 \\
\hline $\mathrm{R}^{2}$ & 0.172 & 0.236 & 0.249 & 0.202 & & 0.260 & 0.284 \\
\hline Average VIF & 1.26 & 1.09 & 1.24 & 1.26 & & 1.09 & 1.24 \\
\hline
\end{tabular}

Notes. *, **, *** denote a significance of $10 \% ; 5 \%$ and $1 \%$, respectively. Models (i) and (iv) - Effect of the diversity of the executive board. Models (ii) and (v) - Effect of the diversity of the board of directors. Model (iii) and (vi) Effect of the diversity of the executive management and the board of directors. CSR = average of the dimensions of community, employees, environment and governance. CSR_EEC = average of the employees, environment and community dimensions. PW_BOARD = proportion of women on the board of directors. AGE_CV_BOARD = age heterogeneity of the members of the board of directors. PW_EXECUTIVE = proportion of women on the top management team. AGE_CV_EXECUTIVE = age heterogeneity of the members of the top management team. SIZE_BOARD = number of members on the board of directors. IND_BOARD = board of directors' independence dummy. SIZE_EXECUTIVE = number of members on the top management team. ROA = return on assets. SIZE = firm size. Coefficients and standard errors (in parentheses) are robustly estimated for heteroscedasticity. Values of the Variance Inflation Factors (VIF) for all independent variables greater than 1 and less than 10, indicating the absence of a multicollinearity problem.

Source: Research data. 
BBR

18

132

Table 4

Diversity, considering female participation, age group and CSR

\begin{tabular}{|c|c|c|c|c|c|c|c|}
\hline \multirow{2}{*}{$\begin{array}{l}\text { Variables } \\
\text { Explanatory }\end{array}$} & \multicolumn{3}{|c|}{$\begin{array}{c}\text { Dependent: CSR (Community, } \\
\text { Employees, Environment and } \\
\text { Governance) }\end{array}$} & \multicolumn{4}{|c|}{$\begin{array}{l}\text { Dependent: CSR_EEC (Employees, } \\
\text { Environment and Community) }\end{array}$} \\
\hline & (vii) & (viii) & (ix) & $(\mathrm{x})$ & & (xi) & (xii) \\
\hline \multirow[t]{2}{*}{ PW_BOARD } & & $8.942 * *$ & $6.276^{*}$ & & & $9.572 * *$ & $7.004 *$ \\
\hline & & $(3.941)$ & $(3.716)$ & & & $(4.435)$ & $(4.083)$ \\
\hline \multirow[t]{2}{*}{ AGE_AVE_BOARD } & & 0.029 & -0.119 & & & 0.106 & -0.065 \\
\hline & & $(0.099)$ & $(0.096)$ & & & $(0.112)$ & $(0.105)$ \\
\hline \multirow[t]{2}{*}{ PW_EXECUTIVE } & 0.430 & & -1.345 & -0.925 & & & -2.31 \\
\hline & $(2.701)$ & & $(2.703)$ & $(2.992)$ & & & $(2.962)$ \\
\hline \multirow[t]{2}{*}{ AGE_AVE_EXECUTIVE } & $0.336^{* * *}$ & & $0.374^{* * *}$ & 0.424 & $* * *$ & & $0.432 * * *$ \\
\hline & $(0.087)$ & & $(0.082)$ & $(0.093)$ & & & $(0.089)$ \\
\hline \multirow[t]{2}{*}{ SIZE_BOARD } & & $0.196^{*}$ & 0.153 & & & $0.257^{* *}$ & $0.198^{*}$ \\
\hline & & $(0.106)$ & $(0.098)$ & & & $(0.119)$ & $(0.109)$ \\
\hline \multirow[t]{2}{*}{ IND_BOARD } & & 0.008 & 0.755 & & & -1.149 & -0.486 \\
\hline & & $(1.217)$ & $(1.110)$ & & & $(1.462)$ & $(1.323)$ \\
\hline \multirow[t]{2}{*}{ SIZE_EXECUTIVE } & 0.024 & & 0.035 & -0.0004 & & & 0.001 \\
\hline & $(0.030)$ & & $(0.032)$ & $(0.032)$ & & & $(0.036)$ \\
\hline \multirow[t]{2}{*}{ ROA } & $-11.387^{*}$ & -9.197 & $-11.474^{*}$ & -10.729 & * & -8.547 & $-11.172^{*}$ \\
\hline & $(6.107)$ & $(6.147)$ & $(6.05)$ & $(6.437)$ & & $(6.630)$ & $(6.359)$ \\
\hline \multirow[t]{2}{*}{ SIZE } & $1.13^{* *}$ & $1.482^{* * *}$ & $1.029^{* *}$ & 1.53 & $* * *$ & $1.772^{* * *}$ & $1.393^{* * *}$ \\
\hline & $(0.365)$ & $(0.289)$ & $(0.360)$ & $(0.406)$ & & $(0.346)$ & $(0.398)$ \\
\hline \multirow[t]{2}{*}{ Constant } & $19.512^{* *}$ & $26.629^{* *}$ & $23.531^{* *}$ & 11.162 & & $20.209^{* *}$ & 14.773 \\
\hline & (7.057) & $(8.253)$ & $(9.430)$ & $(7.781)$ & & $(9.345)$ & $(10.273)$ \\
\hline $\mathrm{N}$ & 150 & 155 & 149 & 150 & & 155 & 149 \\
\hline $\mathrm{F}$ & 14.09 & 7.14 & 9.84 & 15.98 & & 8.15 & 10.29 \\
\hline p-value & 0.000 & 0.000 & 0.000 & 0.000 & & 0.000 & 0.000 \\
\hline $\mathrm{R}^{2}$ & 0.258 & 0.218 & 0.323 & 0.309 & & 0.253 & 0.368 \\
\hline Average VIF & 1.26 & 1.07 & 1.27 & 1.26 & & 1.07 & 1.27 \\
\hline
\end{tabular}

Notes. ${ }^{*},{ }^{* *},{ }^{* * *}$ denote a significance of $10 \% ; 5 \%$ and $1 \%$, respectively. Models (vii) and (x) - Effect of the diversity of the executive management. Models (viii) and (xi) - Effect of the diversity of the board of directors. Model (ix) and (xii) - Effect of the diversity of the executive management and the board of directors. CSR = average of the dimensions of community, employees, environment and corporate governance. CSR_EEC = average of the employees, environment and community dimensions. PW_BOARD = proportion of women on the board of directors. AGE_AVE_BOARD = age group of board members. PW_EXECUTIVE = proportion of women on the top management team. AGE_AVE_EXECUTIVE = age group of the members of the top management team. SIZE_BOARD $=$ number of members of the board of directors. IND_BOARD $=$ board of directors' independence dummy. SIZE_EXECUTIVE = number of members of the top management team. ROA = return on assets. SIZE = firm size. Coefficients and standard errors (in parentheses) are robustly estimated for heteroscedasticity. Values of the Variance Inflation Factors (VIF) of all independent variables greater than 1 and less than 10 indicating the absence of a multicollinearity problem.

Source: Research data. 
Table 4 presents estimates of the six models that analyze the effect of diversity on CSR, taking into account the age group of the board of directors and top management team. The results confirm that women on the board of directors (PW_BOARD) do indeed have a positive influence on CSR. The positive effect was found in all the models, endorsing the suggestion that female presence on the board favors the CSR of Brazilian firms (Hypothesis 1a). It is noteworthy that the board composition is responsible for the judgment, advice and drafting of strategic firm policies.

In addition, the age group of the top management team (AGE_AVE_EXECUTIVE) has a positive effect on all the models (vii, viii, ix, $x$, xi, xii), suggesting that a higher age group on the board positively influences CSR and governance, as hypothesized (Hypothesis $3 \mathrm{~b}$ ). The high age group means that top managers have more relevant experience and knowledge when implementing strategies established by the board of directors. It was observed that more experienced top managers, probably with a more highly developed moral capacity, are more likely to undertake CSR.

Contrary to expectations, there was no effect of the age group of the board of directors (AGE_AVE_BOARD) on CSR of Brazilian firms (Hypothesis 3a). Likewise, the presence of women on the top management team (PW_EXECUTIVE) is also not capable of affecting the CSR of Brazilian firms (Hypothesis 1b), confirming the previous findings. It is noteworthy that this result can be justified by the low representation of women in the top management team. The empirical evidence shows that when minorities are largely underrepresented in a team, they tend to have no voice compared with the majority group members. However, when the minority forms a critical mass in a group, interpersonal interactions improve (Post et al., 2011).

The results confirm that the size of the board of directors (SIZE_BOARD) tends to affect CSR positively. Likewise, firm size (SIZE) is highlighted as capable of boosting the CSR of Brazilian firms. The research findings corroborate the international literature (Bear et al., 2010; Galbreath, 2011; Post et al., 2011), by stating that a board of directors with a strong female presence is more concerned with stakeholder engagement, and that a higher age group of top managers is favorable to decisions to improve CSR and corporate governance. In this sense, with the formation of such a situation in a firm, greater concern is expected over issues that bring benefits not only to shareholders, but also to society as a whole. From the results obtained in the econometric models, it was possible to verify the effects of the diversity of the board of directors and top management team on CSR. The main results obtained in the survey are summarized in Chart 3.

Based on the information shown in Chart 3, Hypotheses 1a and $3 \mathrm{~b}$ were confirmed, in keeping with the proposals of Stakeholder Theory and the arguments of Bear et al. (2010) and Galbreath (2011). Furthermore, a negative influence of the heterogeneous age of members of the board of directors on CSR was found, contrary to expectations. 
Chart 3

Summary of results

\begin{tabular}{|c|c|c|c|c|}
\hline Variable & $\begin{array}{c}\text { Expected } \\
\text { result }\end{array}$ & Theoretical basis & Obtained result & $\begin{array}{c}\text { Conclusion on } \\
\text { the hypothesis }\end{array}$ \\
\hline $\begin{array}{c}\text { Women on the board of } \\
\text { directors } \\
\text { (PW_BOARD) }\end{array}$ & + & $\begin{array}{c}\text { Bernardi and } \\
\text { Threadgill (2010); } \\
\text { Glass et al. (2016) }\end{array}$ & + & $\begin{array}{c}\text { Confirmed } \\
\text { (Hypothesis 1a) }\end{array}$ \\
\hline $\begin{array}{c}\text { Women in the top } \\
\text { management team } \\
\text { (PW_EXECUTIVE) }\end{array}$ & + & $\begin{array}{c}\text { Bernardi and } \\
\text { Threadgill (2010); } \\
\text { Glass et al. (2016) }\end{array}$ & Not significant & $\begin{array}{c}\text { Not confirmed } \\
\text { (Hypothesis 1b) }\end{array}$ \\
\hline $\begin{array}{c}\text { Age heterogeneity of members } \\
\text { of the board of directors } \\
\text { (AGE_CV_BOARD) }\end{array}$ & + & $\begin{array}{c}\text { Ferrero-Ferrero et al. } \\
(2013)\end{array}$ & - & $\begin{array}{c}\text { Not confirmed } \\
\text { (Hypothesis 2a) }\end{array}$ \\
\hline $\begin{array}{c}\text { Age heterogeneity of members } \\
\text { of the top management team } \\
\text { (AGE_CV_EXECUTIVE) }\end{array}$ & + & $\begin{array}{c}\text { Ferrero-Ferrero et al. } \\
(2013)\end{array}$ & Not significant & $\begin{array}{c}\text { Not confirmed } \\
\text { (Hypothesis 2b) }\end{array}$ \\
\hline $\begin{array}{c}\text { Age group of members of the } \\
\text { board of directors } \\
\text { (AGE_AVE_BOARD) }\end{array}$ & + & $\begin{array}{c}\text { Giannarakis (2014); } \\
\text { Post et al. (2011) }\end{array}$ & Not significant & $\begin{array}{c}\text { Not confirmed } \\
\text { (Hypothesis 3a) }\end{array}$ \\
\hline $\begin{array}{c}\text { Age group of members of the } \\
\text { top management team } \\
\text { (AGE_AVE_EXECUTIVE) }\end{array}$ & + & $\begin{array}{c}\text { Giannarakis (2014); } \\
\text { Post et al. (2011) }\end{array}$ & + & $\begin{array}{c}\text { Confirmed } \\
\text { (Hypothesis 3b) }\end{array}$ \\
\hline
\end{tabular}

Source: Prepared by the authors.

\section{FINAL REMARKS}

The study analyzed the effects of diversity in the composition of the board of directors and top management team on the CSR of Brazilian firms. The general index established by the CSRHub was used as proxy for CSR, and this index was also considered without the corporate governance component (CSR_EEC). For diversity in the board of directors and top management team, gender and age were considered: the proportion of female members was taken into account to address the gender effect; and for age, the age heterogeneity (the coefficient of variation among members) and the age group obtained by the average age of members.

On the whole, the results reveal characteristics of the board of directors and top management team of Brazilian firms: low presence of women; high age group, as usually documented in the literature, and age homogeneity. Multivariate analysis provided support for two hypotheses: (1) the presence of women on the board of directors positively influences the CSR level of Brazilian firms (Hypothesis 1a), confirming that women tend to be more sensitive to CSR issues and (2) the high age group of directors and top managers favors Brazilian firm CSR policy (Hypothesis $3 b)$, suggesting that older people are more committed to social welfare. On the other hand, the unexpected evidence related to the negative effect of age dispersion of board members (Hypothesis $2 \mathrm{a}$ ) is a sign that the high disparity among them concerning experience, knowledge, and views, which may be increased through age diversity, has not benefitted the CSR policy of Brazilian firms. Indeed, this age heterogeneity on the board of directors may be leading to conflicts between generations, with a negative impact on CSR. This finding signals a starting point for other research approaches on the topic.

This research contributes to the analysis of diversity in the composition of the board and top management team and CSR in the Brazilian market, given the important relationship that the 
board and top management team may establish between the firm and its stakeholders. Specifically, the work assesses the effect of demographic diversity (based on gender and age) of members of the board of directors and top management team and its possible effect on CSR performance. This represents an advance in Brazil considering that previous studies in this respect analyzed the CSR-financial performance relationship and focused more on the diversity of the board of directors only.

A limitation of the study is the selection of diversity variables, since the literature presents other metrics for this evaluation. Another limitation is the non-probabilistic sample and the short analysis period, which prevent a generalization of the results. Future research may consider a longer period with a probabilistic sample, including firms listed on stock exchanges in different countries, the use of other diversity metrics, such as nationality, ethnicity, and the professional experience of members. This would allow a more in-depth analysis of diversity in the members of boards and top management teams.

\section{REFERENCES}

Aggarwal, P. (2013). Impact of corporate governance on corporate financial performance. Journal of Business and Management, 13(3), 1-5.

Al-Shaer, H., \& Zaman, M. (2016). Board gender diversity and sustainability reporting quality. Journal of Contemporary Accounting and Economics, 12(3), 210-222. https://doi.org/10.1016/j. jcae.2016.09.001

Almeida, F. T. de, Parente, P. H. N., De Luca, M. M. M., \& Vasconcelos, A. C. de. (2018). Governança corporativa e desempenho empresarial: uma análise nas empresas brasileiras de construção e engenharia. Gestão \& Regionalidade, 34(100), 110-126. https://doi.org/10.13037/gr.vol34n100.3594

Almeida, R. S., Klotzle, M. C., \& Pinto, A. C. (2013). Composição do conselho de administração no setor de energia elétrica do brasil. Revista de Administração Da UNIMEP, 11(1), 156-180.

Arena, C., Bozzolan, S., \& Michelon, G. (2015). Environmental reporting: transparency to stakeholders or stakeholder manipulation? An analysis of disclosure tone and the role of the board of directors. Corporate Social Responsibility and Environmental Management, 22(6), 346-361. https://doi. org/10.1002/csr. 1350

Arminen, H., Puumalainen, K., Pätäri, S., \& Fellnhofer, K. (2018). Corporate social performance: inter-industry and international differences. Journal of Cleaner Production, 177, 426-437. https:// doi.org/10.1016/j.jclepro.2017.12.250

Assenga, M. P., Aly, D., \& Hussainey, K. (2018). The impact of board characteristics on the financial performance of Tanzanian firms. Corporate Governance: The International Journal of Business in Society. https://doi.org/10.1108/CG-09-2016-0174

Bear, S., Rahman, N., \& Post, C. (2010). The impact of board diversity and gender composition on corporate social responsibility and firm reputation. Journal of Business Ethics, 97(2), 207-221. https://doi.org/10.1007/s10551-010-0505-2

Bejar, S., Mukherjee, B., \& Moore, W. H. (2011). Time horizons matter: the hazard rate of coalition governments and the size of government. Economics of Governance, 12(3), 201-235. https://doi. org/10.1007/s10101-011-0096-0

Bernardi, R. A., \& Threadgill, V. H. (2010). Women directors and corporate social responsibility. EJBO - Electronic Journal of Business Ethics and Organization Studies, 15(2), 15-21. 
BBR

18

136

Bouvain, P., Baumann, C., \& Lundmark, E. (2013). Corporate social responsability in financial services. International Journal of Back Marketing, 31(6), 420-439. https://doi. org/10.1108/09574090910954864

Byron, K., \& Post, C. (2016). Women on boards of directors and corporate social performance: a meta-analysis. Corporate Governance: An International Review. https://doi.org/10.1111/corg.12165

Campbell, K., \& Mínguez-Vera, A. (2008). Gender Diversity in the Boardroom and Firm Financial Performance. Journal of Business Ethhics, 83(1), 435-451. https://doi.org/10.1007/s10551-0079630-y

Costa, L., Sampaio, J. O., \& Flores, E. S. (2019). Diversidade de gênero nos conselhos administrativos e sua relaçáo com desempenho e risco financeiro nas empresas familiares. Revista de Administração Contemporânea, 23(6), 721-738.

Crisóstomo, V. L., Freire, F. de S., \& Vasconcellos, F. C. de. (2011). Corporate social responsibility, firm value and financial performance in Brazil. Social Responsibility Journal, 7(2), 295-309. https:// doi.org/10.1108/17471111111141549

CSRHub. (2019). Sustainability management tools: about csrhub. Retrieved from https://esg.csrhub. com/about-csrhub.

Dani, A. C., Picolo, J. D., \& Klann, R. C. (2018). Gender influence, social responsibility and governance in performance. RAUSP Management Journal. https://doi.org/10.1108/RAUSP-07-2018-0041

Deshmukh, S., Goel, A. M., \& Howe, K. M. (2013). CEO overconfidence and dividend policy. Journal of Financial Intermediation, 22(3), 440-463. https://doi.org/10.1016/j.jfi.2013.02.003

Ferrero-Ferrero, I., Fernández-Izquierdo, M. Á., \& Muñoz-Torres, M. J. (2013). Integrating sustainability into corporate governance: an empirical study on board diversity. Corporate Social Responsibility and Environmental Management, 22(4), 193-207. https://doi.org/10.1002/csr.1333

Fraga, J. B., \& Silva, V. A. B. (2012). Diversidade no conselho de administração e desempenho da empresa: uma investigação empírica. Brazilian Business Review, 9(Especial), 58-80.

Fuente, J. A., García-Sánchez, I. M., \& Lozano, M. B. (2017). The role of the board of directors in the adoption of GRI guidelines for the disclosure of CSR information. Journal of Cleaner Production, 141, 737-750. https://doi.org/10.1016/j.jclepro.2016.09.155

Galbreath, J. (2011). Are there gender-related influences on corporate sustainability? A study of women on boards of directors. Journal of Management \& Organization, 17(1), 17-38. https://doi. org/10.1017/S1833367200001693

Giannarakis, G. (2014). The determinants influencing the extent of CSR disclosure. International Journal of Law and Management, 56(5), 393-416. https://doi.org/10.1108/IJLMA-05-2013-0021

Glass, C., Cook, A., \& Ingersoll, A. R. (2016). Do women leaders promote sustainability? Analyzing the effect of corporate governance composition on environmental performance. Business Strategy and the Environment, 25(7), 495-511. https://doi.org/10.1002/bse.1879

Hafsi, T., \& Turgut, G. (2013). Boardroom diversity and its effect on social performance: conceptualization and empirical evidence. Journal of Business Ethics, 112(3), 463-479. https:// doi.org/10.1007/s10551-012-1272-z

Hughey, C., \& Sulkowski, A. (2012). More disclosure = better CSR reputation? An examination of CSR reputation leadres and laggards in the global oil and gas industry. Journal of Academy of Business and Economics, 12(2), 24-34. 
IBGC, I. B. de G. C. (2015). Código das melhores práticas de governança corporativa (5th ed.). São Paulo: IBGC.

Ibrahim, A. H., \& Hanefah, M. M. (2016). Board diversity and corporate social responsibility in Jordan. Journal of Financial Reporting and Accounting, 14(2), 279-298. https://doi.org/10.1108/ JFRA-06-2015-0065

Instituto Brasileiro de Governança Corporativa - IBGC. (2015). Código das melhores práticas de governança corporativa (5th ed.). São Paulo: IBGC.

Instituto Brasileiro De Governança Corporativa - IBGC. (2016). Perfil dos conselhos de administração. São Paulo: IBGC.

Jizi, M. (2017). The influence of board composition on sustainable development disclosure. Business Strategy and the Environment, 26(5), 640-655. https://doi.org/10.1002/bse.1943

Kang, W. I. kuk, \& Fornes, G. (2017). Where are they going? Case of British and Japanese human resource management. Journal of Asia Business Studies, 11(3), 296-322. https://doi.org/10.1108/ JABS-07-2015-0111

Kassinis, G., \& Vafeas, N. (2002). Corporate boards and outside stakeholders as determinants of environmental litigation. Strategic Management Journal, 23(5), 399-415. https://doi.org/10.1002/ smj. 230

Macedo, Á. F. P. de, Oliveira, A. M., Nobre, L. N., Brito, S. G., \& Quandt, C. O. (2015). Governança corporativa e evidenciação de capital intelectual em empresas brasileiras. Revista Evidenciação Contábil \& Finanças, 3(1), 18-33. https://doi.org/10.18405/recfin20150102

Mohamed, I. M. A., \& Salah, W. (2016). Investigating corporate social responsibility disclosure by banks from institutional theory perspective. Journal of Administrative and Business Studies, 2(6), 280-293. https://doi.org/10.20474/jabs-2.6.3

Projeto de Lei do Senado no 112 (2010). Projeto de Lei do Senado no 112, de 27 de abril de 2010, que define o percentual minimo de participação de mulheres nos conselhos de administração das empresas públicas e sociedades de economia mista, suas subsidiárias e controladas e demais empresas em que a Uniäo, direta ou indiretamente, detenha a maioria do capital social com direito a voto. Retrieved from https://www25.senado.leg.br/web/atividade/materias/-/materia/96597

Projeto de Lei do Senado no 398 (2016). Projeto de Lei do Senado no 398, de 26 de outubro de 2016, que altera a Lei $n^{\circ} 6.404$, de 15 de dezembro de 1976, para estabelecer a reserva de um percentual minimo para cada gênero nos conselhos de administração das companhias abertas. Retrieved from https://www25.senado.leg.br/web/atividade/materias/-/materia/127328

Post, C., Rahman, N., \& Rubow, E. (2011). Green governance: boards of directors' composition and environmental corporate social responsibility. Business and Society, 50(1), 189-223. https:// doi.org/10.1177/0007650310394642

Rao, K., \& Tilt, C. (2016a). Board composition and corporate social responsibility: the role of diversity, gender, strategy and decision making. Journal of Business Ethics, 138(2), 327-347. https:// doi.org/10.1007/s10551-015-2613-5

Rao, K., \& Tilt, C. (2016b). Board diversity and CSR reporting: an australian study. Meditary Accountancy Research, 24(2), 182-210. https://doi.org/http://dx.doi.org/10.1108/MRR-09-20150216 
BBR

18

138
Ricardo, V. S., Barcellos, S. S., \& Bortolon, P. M. (2017). Relatório de sustentabilidade ou relato integrado das empresas listadas na BM\&FBovespa: fatores determinantes de divulgação. Revista de Gestão Social e Ambiental, 11(1), 90-104.

Rocha, R. M., Santos, T. M. N., De Luca, M. M. M., \& Vasconcelos, A. C. de. (2014). Conselho de administração e desempenho nas maiores companhias listadas na BM\&FBOVESPA. In $V$ Congresso Nacional de Administração e Ciências Contábeis (pp. 1-16).

Said, R., Zainuddin, Y., \& Haron, H. (2009). The relationship between corporate social responsibility disclosure and corporate governance characteristics in Malaysian public listed companies. Social Responsibility Journal, 5(2), 212-226. https://doi.org/10.1108/17471110910964496

Sant'anna, V. S., \& Bruzoni Júnior, A. C. (2019). Governança corporativa, TMT e book-tax differences (BTD) anormais em empresas de capital aberto listadas no Brasil. Advances in Scientific and Applied Accounting, 12(2), 165-187.

Santana, L. M. de, Góis, A. D., De Luca, M. M. M., \& Vasconcelos, A. C. de. (2015). Relação entre disclosure socioambiental, práticas de governança corporativa e desempenho empresarial. Revista Organizaçôes Em Contexto, 11(21), 49-72. https://doi.org/10.15603/1982-8756/roc

Silva, A. L. C. da, \& Margem, H. (2015). Mulheres em cargos de alta administração afetam o valor e desempenho das empresas brasileiras? Revista Brasileira de Finanças (Online), 13(1), 102-133. Retrieved from http://bibliotecadigital.fgv.br/ojs/index.php/rbfin/article/viewFile/35116/56019

Silva Júnior, C. P. da, \& Martins, O. S. (2017). Mulheres no conselho afetam o desempenho financeiro? Uma análise da representação feminina nas empresas listadas na BM\&FBOVESPA. Revista Sociedade, Contabilidade e Gestão, 12(1), 63-76. https://doi.org/10.21446/scg_ufrj.v12i1.13398

Silveira, A. di M. da, \& Donaggio, A. R. F. (2019). A importância da diversidade de gênero nos conselhos de administração para a promoção da responsabilidade social corporativa. Direito, Economia e Sociedade Contemporânea, 2(2), 11-42.

Skouloudis, A., Evangelinos, K., \& Kourmousis, F. (2009). Development of an evaluation methodology for triple bottom line reports using international standards on reporting. Environmental Management, 44(2), 298-311. https://doi.org/10.1007/s00267-009-9305-9

Taghizadeh, M., \& Saremi, S. Y. (2013). Board of directors and firms performance: evidence from malaysian public listed firm. International Proceedings of Economics Development and Research, 59(37), 178-182. https://doi.org/10.7763/IPEDR.

Vaia, G., Bisogno, M., \& Tommasetti, A. (2017). Investigating the relationship between the social and economic-financial performance. Applied Finance and Accounting, 3(1), 55. https://doi. org/10.11114/afa.v3i1.2126

Walt, N. Van Der, \& Ingley, C. (2003). Board dynamics and the influence of professional background, gender and ethnic diversity of directors. Corporate Governance, 11(3), 218-234.

Westermann, S., Niblock, S. J., \& Kortt, M. A. (2019). Does it pay to be responsible? An empirical investigation of corporate social responsibility and REITs in Australia. Asia-Pacific Journal of Accounting and Economics. https://doi.org/https://doi.org/10.1080/16081625.2019.1673188 


\section{AUTHOR'S CONTRIBUTION}

The contributions of the first author were the data collection, data treatment, structuring of econometric models, model estimation, data analysis and drafting of the text. The second author contributed to the work through the data collection, data treatment, structuring of econometric models, model estimation, data analysis and drafting of the text. The third author contributed to the work through the treatment of data, structuring of econometric models, estimation of models, data analysis, drafting of the text, guidance and conducting research. The fourth author contributed to the work through the structuring of econometric models, data analysis, drafting the text, providing guidance and conducting research.

\section{CONFLICTS OF INTEREST}

The authors declare that there is no conflict of interest regarding the content of this work. 